\title{
Implikasi Yuridis Perjanjian Koalisi Politik yang Dibuat di Hadapan Notaris
}

\author{
Nur Kholiq \\ kholiq.jpr@gmail.com
}

\begin{abstract}
In 2010, Purworejo District held the Regional Head Election (Pilkada) directly. The author conducted a study of the political coalition agreement in the Purworejo District Election in 2010 by formulating the problem of how to implement the political coalition agreement and how its juridical implications. The chosen research is qualitative research that produces descriptive data. The approach chosen in this legal research is nominative-empirical, that is, regarding the implementation of normative legal provisions in action on any particular legal action during the implementation of the Purworejo District Election in 2010. From the research, the author found the role of a Notary in making political coalition agreements in District Election Purworejo. In its implementation, there are two categories of parties to the agreement. First, the agreement between the prospective regent candidates and the regent candidates who are stated in an authentic deed and made before a Notary. Second, the agreement is underhanded between the candidates for the regent and the leaders of the political party who carry it. The political coalition agreement does not have direct juridical implications for the validity of the Purworejo district election process. The agreement also cannot be used as a strong evidence for filing a lawsuit / dispute to court even though the party has found a default.
\end{abstract}

Keywords: Political coalition; agreement; notary

\begin{abstract}
Abstrak
Pada 2010, Kabupaten Purworejo menyelenggarakan Pemilihan Kepala Daerah (Pilkada) secara langsung. Penulis melakukan penelitian terhadap perjanjian koalisi politik dalam Pilkada Kabupaten Purworejo tahun 2010 dengan merumuskan permasalahan tentang bagaimana pelaksanaan perjanjian koalisi politik tersebut serta bagaimana implikasi yuridisnya . Penelitian yang dipilih adalah penelitian kualitatif yang mengahasilkan data diskriptif. Pendekatan yang dipilih dalam penelitian hukum ini adalah nomatif-empiris, yaitu mengenai implementasi ketentuan hukum normatif dalam aksinya pada setiap perbuatan hukum tertentu selama pelaksanaan Pilkada Kabupaten Purworejo tahun 2010. Dari penelitian tersebut, penulis menyimpulkan adanya peran Notaris dalam membuat perjanjian koalisi politik pada Pilkada Kabupaten Purworejo. Dalam pelaksanaanya, ada dua kategori para pihak pada perjanjian tersebut. Pertama, perjanjian antara bakal calon bupati dengan bakal calon bupati yang dituangkan dalam akta autentik dan dibuat di hadapan Notaris. Kedua, perjanjian di bawah tangan antara bakal calon bupati dengan pimpinan partai politik pengusung. Perjanjian koalisi politik tersebut tidak memiliki implikasi yuridis secara langsung terhadap keabsahan proses Pilkada Kabupaten Purworejo. Perjanjian tersebut juga tidak bisa digunakan sebagai alat bukti yang kuat untuk pengajuan gugatan/sengketa ke pengadilan meskipun ditemukan tindakan wanprestasi dari salah satu pihak.
\end{abstract}

Kata-kata Kunci: Koalisi politik; perjanjian; notaris 


\section{Pendahuluan}

Salah satu perubahan politik hukum sebagai implikasi dari perubahan UUD 1945 adalah terkait dengan pemilihan kepala daerah (Pilkada), baik gubernur dan wakil gubernur, bupati dan wakil bupati, maupun walikota dan wakil walikota. Meskipun UUD 1945 hanya implisit menyatakan kepala daerah dipilih secara demokratis sebagaimana tertuang dalam Pasal 18 ayat (4), namun penafsiran terhadap pasal ini sedikit banyak dipengarui juga dengan politik hukum atas pasal tentang pemilihan presiden dan wakil presiden hingga akhirnya dalam undangundang sebagai aturan turunannya ditentukan bahwa kepala daerah dipilih secara langsung.

Meskipun dinamikanya pada saat revisi undang-undang Pilkada sempat terjadi perdebatan terkait mekanisme pemilihan secara langsung atau perwakilan, namun akhirnya yang disahkan adalah kepala daerah tetap dipilih secara langsung. Model pemilihan langsung, baik presiden dan wakil presiden yang pertama kali terjadi 2004, kepala daerah 2005, termasuk juga pemilihan anggota legislatif inilah memunculkan fenomena dan gejala baru di masyarakat.

Biyanto, akademisi di Universitas Islam Negeri (UIN) Sunan Ampel Surabaya yang juga Ketua Majelis Dikdasemen Pengurus Wilayah Muhammadiyah (PWM) Provinsi Jawa Timur mencatat, dinamika politik pada pemilihan secara langsung itu telah memunculkan kecenderungan perubahan pola komunikasi yang dilakukan oleh partai politik dengan berbagai pihak. Gerakan dan manuver yang dilakukan elite partai politik yang saling beradu cepat melakukan safari politik dalam rangka menjajaki kemungkinan kerjasama politik. Usaha elite partai untuk membangun kesepahaman politik itulah yang kemudian populer disebut kontrak politik, ${ }^{1}$ yang secara konkrit banyak dituangkan dalam wujud perjanjian koalisi politik secara tertulis. Semenjak itulah kontrak politik menjadi istilah yang sangat populer di kalangan masyarakat, terutama pada saat menjelang pelaksanaan pemilu.

Praktik kontrak atau perjanjian politik juga terjadi pada saat pelaksanaan Pilkada Kabupaten Purworejo 2010. Kontrak dan perjanjian politik tersebut bahkan

\footnotetext{
1 https://nasional.sindonews.com/read/860024/18/budaya-kontrak-politik-1399102380/13 diakses Jumat, 17 Nopember 2017 pukul 10.15 WIB
} 
dilakukan antara elit-elit partai politik dengan para bakal calon serta antar calon sendiri. Kontrak dan perjanjian politik tersebut dilakukan di hadapan sejumlah notaris yang dikehendaki oleh para pihak. Prosesnya sudah dilakukan sejak masa penjaringan bakal calon yang dilakukan oleh partai-partai politik. Bahkan aktifitas kontrak dan perjanjian politik tersebut sangat dinamis karena jumlah bakal calon yang muncul sangat banyak, mencapai sebelas pasangan calon, baik yang melalui jalur partai politik dan atau gabungan partai politik maupun jalur perseorangan.

Kontrak dan perjanjian politik yang muncul pada Pilkada Kabupaten Purworejo 2010 itu berkaitan dengan kesepakatan memberikan dukungan untuk kepentingan pencalonan sebagaimana syarat yang ditentukan dalam undangundang. Dukungan dan kerjasama tersebut dituangkan dalam bentuk perjanjian tertulis yang dibuat di hadapan notaris. Bukan hanya satu pasangan calon dengan pimpinan partai politik saja.

Fenomena perjanjian atau kontrak koalisi partai politik yang terjadi selama Pilkada Kabupaten Purworejo 2010 ini menurut hemat penulis menarik untuk diteliti dan diangkat dalam penulisan tesis. Pasalnya, secara normatif kontrak atau perjanjian sebagai domain hukum privat ternyata digunakan juga untuk perbuatan hukum publik, dalam hal ini kepentingan hukum tata negara.

\section{Rumusan Masalah}

Rumusan masalah dalam penelitian ini sebagai berikut: pertama, bagaimana pelaksanaan perjanjian koalisi politik pada Pilkada Kabupaten Purworejo tahun 2010 dibuat di hadapan notaris ? Kedua, bagaimana implikasi yuridis perjanjian tersebut terhadap pelaksanaan Pilkada Kabupaten Purworejo 2010 ?

\section{Tujuan Penelitian}

Pertama, memahami pelaksanaan perjanjian koalisi politik pada Pilkada Kabupaten Purworejo 2010 dibuat di hadapan notaris. Kedua, mengetahui implikasi yuridis perjanjian tersebut terhadap pelaksanaan Pilkada Kabupaten Purworejo 2010. 


\section{Metode Penelitian}

Berdasarkan perumusan masalah dan tujuan penelitian yang sudah penulis sajikan di depan, maka metode yang digunakan adalah pendekatan normatif-empiris. Seperti disampaikan M Syamsuddin, pendekatan ini merupakan penggabungan antara pendekatan hukum normatif dengan adanya penambahan berbagai unsur yang bersifat empiris. ${ }^{2}$ Metode penelitian normatif-empiris mengenai implementasi ketentuan hukum normatif (undang-undang) dalam aksinya pada setiap perbuatan hukum tertentu yang terjadi dalam suatu masyarakat.

\section{Sumber dan Jenis Data}

Secara umum jenis data yang diperlukan dalam sebuah penelitian hukum terdiri dari data primer, data sekunder, dan data tersier. Namun dalam penelitian ini, data utama yang digunakan penulis adalah data sekunder sebagai berikut : pertama, Bahan hukum primer berupa peraturan perundang-undangan yang mendasari perjanjian dan kontrak, peristiwa perjanjian koalisi partai politik dengan menggali langsung dari para pihak, baik itu calon kepala daerah dan wakil kepala daerah, pimpinan partai politik, notaris, serta praktisi hukum dari hakim pengadilan negeri Purworejo. Kedua, bahan hukum sekunder berupa literatur, karya ilmiah, hasil penelitian, loka karya, serta aturan perundang-undangan yang berkaitan langsung dengan objek penelitian. Ketiga, bahan hukum tersier berupa kamus, artikel pada majalah atau surat kabar untuk melengkapi dan menjelaskan bahan-bahan hukum primer dan sekunder.

Dalam penelitian ini, juga didukung dengan data primer yaitu hasil wawancara dengan pihak-pihak yang terkait secara langsung dengan perjanjian koalisi politik pada Pilkada Kabupaten Purworejo tahun 2010 yang dibuat di hadapan notaris.

\section{Metode Pengumpulan Data}

Metode pengumpulan data yang digunakan dalam penelitian ini adalah dengan melakukan wawancara dan studi pustaka. Wawancara adalah bentuk

${ }^{2}$ M Syamsuddin, Operasionalisasi Penelitian Hukum, Rajawali Pers, Jakarta, 2007, hlm. 36 
komunikasi antara dua orang melibatkan seseorang yang lain, memperoleh informasi dari seseorang yang lainya dengan mengajukan pertanyaan-pertanyaan berdasarkan tujuan tertentu. ${ }^{3}$ Studi Pustaka dengan cara mencari dan mengumpulkan bahan-bahan yang terkait dengan masalah yang diangkat dalam penelitian tesis ini. Data yang diperoleh akan disajikan dalam bentuk diskriptis, kemudian dianalisis dengan menggunakan metode yuridis kualitatif.

\section{Hasil Penelitian dan Pembahasan}

\section{Pelaksanaan Pilkada Kabupaten Purworejo 2010}

Di Kabupaten Purworejo, Pilkada 2010 merupakan pengalaman kedua dalam pemilihan kepala daerah dan wakil kepala daerah secara langsung. Sebelumnya, pada 2005 Kabupaten Purworejo juga telah menyelenggarakan Pilkada secara langsung. Namun penulis hanya akan melakukan pembahasan untuk pelaksanaan Pilkada tahun 2010 yang merupakan obyek dari penelitian penyusunan tesis ini.

Dasar hukum pelaksanaan Pilkada secara nasional saat itu mengacu pada ketentuan dalam Undang-Undang Nomor 32 Tahun 2004 tentang Pemerintahan Daerah. Pada Pilkada Kabupaten Purworejo 2005 masih mengacu pada UndangUndang Nomor 32 Tahun 2004 tersebut. Dalam perkembangannya, dinamika politik mendorong terjadinya revisi terbatas atas undang-undang tersebut dan akhirnya lahir Undang-Undang Nomor 22 Tahun 2008 tentang Revisi UndangUndang Nomor 32 Tahun 2004.

Salah satu aspek penting dari revisi regulasi tersebut adalah muncunya ketentuan tentang calon perseorangan seiring dengan lahirnya Keputusan Mahkamah Konstitusi yang menganulir sejumlah pasal dalam Undang-Undang Nomor 32 Tahun 2004 yang dinilai bertentangan dengan prinsip-prinsip dasar demokrasi sebagaimana tercantum dalam UUD 1945 Pasal 18 ayat (3) dan ayat (4) dan Pasal 22 E.

Selain undang-undang tentang Pemerintahan Daerah tersebut, dasar hukum pelaksanaan Pilkada Kabupaten Purworejo 2010 adalah Undang-Undang Nomor

\footnotetext{
${ }^{3}$ Mulyana Deddy, Metodologi Penelitian Kualitatif; Paradigma Baru Ilmu Komunikasi dan Ilmu Sosial Lainnya, PT Remaja Rosidakarya, Bandung, 2004, hlm. 56.
} 
22 Tahun 2007 tentang Penyelenggara Pemilu. Undang-undang ini secara khusus mengatur tugas dan kewajiban badan penyelenggara pemilu, baik itu Komisi Pemilihan Umum (KPU) maupun Panitia Pengawas Pemilu (Panwaslu). Pemberlakuan Undang-Undang Nomor 22 Tahun 2007 menjadikan pelaksanaan Pilkada menjadi bagian dari rezim Pemilu sebagaimana halnya pemilu legislatif dan pemilu presiden.

Selain 3 dasar hukum di atas, pelaksanaan Pilkada secara teknis diatur dalam bentuk Peraturan Pemerintah (PP) yang merupakan penjabaran dari UndangUndang Nomor 32 Tahun 2004 dan atau Undang-Tndang Nomor 12 Tahun 2008 beserta seperangkat regulasi yang bersumber dan merupakan pejabaran dari undang-undang tersebut. Dalam teknis pelaksanaanya, KPU menetapakan tahapan-tahapan teknis dan jadwal pelaksanaan Pilkada.

\section{Perjanjian Koalisi Politik dalam Dinamika Penggalangan Dukungan}

Pelaksanaan Pilkada di semua daerah selalu memaparkan dinamika yang luar biasa dan dialami oleh banyak kalangan, baik itu bakal calon, pimpinan partai politik, organisasi sosial kemasyarakatan dan secara umum elemen demokrasi. Dinamika yang sama juga terjadi pada saat pelaksanaan Pilkada Kabupaten Purworejo. Namun, dalam penulisan tesis ini, penulis hanya akan memaparkan dinamika-dinamika faktual yang terjadi sepanjang tahapan pra pencalonan yang terkait secara langsung dengan obyek penelitian.

Dinamika yang paling menonjol adalah pra tahapan pencalonan. Bakal pasangan calon maupun pimpinan partai politik menjalani pergulatan dua dimensi sekaligus, yaitu dimensi yuridis untuk memenuhi persyaratan yang ditentukan oleh regulasi sekaligus dimensi politik sebagai bagian tak terpisahkan untuk memenuhi persyaratan yuridis. Penggalangan dukungan, baik oleh bakal calon yang diusung partai politik dan atau gabungan partai politik maupun bakal calon dari jalur perseorangan. Perjanjian koalisi politik adalah salah satu bentuk dinamika yang terpotret dari usaha-usaha penggalangan dukungan untuk memenuhi persyaratan yuridis yang ditentukan oleh regulasi.

Mencermati ketentuan regulasi, sebenarnya tidak ada persyaratan yang mengharuskan bakal calon melakukan perbuatan hukum berupa perjanjian koalisi 
politik. Namun, langkah-langkah hukum dengan tendensi politik itu ditempuh oleh beberapa bakal calon untuk mendapatkan dukungan politik agar bisa memenuhi persyaratan yuridis dan bisa mendaftar dengan tujuan bisa ditetapkan sebagai pasangan calon peserta Pilkada. KPU yang bekerja berdasarkan ketentuan regulasi sebenarnya tidak meminta persyaratan adanya perjanjian koalisi politik dari bakal calon dengan partai politik atau gabungan partai politik pengusung. Termasuk tidak adanya persyaratan perjanjian politik antara bakal calon bupati dengan bakal calon wakil bupati atau antara bakal calon dengan pimpinan ormas atau lembaga tertentu. Namun demikian, sepanjang pelaksanaan Pilkada Kabupaten Purworejo 2010, beberapa bakal calon melaksanakan perjanjian koalisi politik tersebut, bahkan beberapa di antaranya melibatkan pejabat umum notaris untuk melakukan pencatatan perjanjian dengan maksud dan tujuan agar perjanjian tersebut memiliki legitimasi dari aspek hukum.

Perbuatan hukum dalam wujud perjanjian koalisi politik ini dilakukan pada saat pra tahapan pencalonan. Pada pelaksanaan Pilkada Kabupaten Purworejo, penulis menemukan fakta bahwa perjanjian koalisi yang sekaligus dalam rangka penggalangan dukungan itu dilakukan oleh bakal calon dari jalur pengusungan partai politik dan gabungan partai politik serta dari jalur perseorangan. Perbuatan hukum berupa perjanjian koalisi politik itu terjadi antara para pihak yang antara lain meliputi: pertama, perjanjian antara bakal calon bupati dengan bakal calon wakil bupati, dan Kedua, perjanjian antara bakal calon dengan pimpinan partai politik pengusung

\section{Perjanjian antara Bakal Calon Bupati dengan Bakal Calon Wakil Bupati}

Dalam penelitian terhadap pra tahapan pencalonan pada Pilkada Kabupaten Purworejo 2010, penulis menemukan adanya perbuatan hukum berupa pelaksanaan perjanjian yang para pihaknya terdiri dari bakal calon bupati dan bakal calon wakil bupati. Perjanjian ini dilakukan oleh bakal calon yang diusung gabungan partai politik yang sebagian besar tidak memiliki kursi di DPRD Kabupaten Purworejo, yaitu antara bakal calon bupati Ir. Akhmad Fauzi, MA dengan bakal calon wakil bupati Supeniwati. Kedua bakal calon tersebut diusung 
oleh gabungan partai yang terdiri dari PBB, Patriot, PKNU, PPRN, PDS, Hanura, PKPB, PRN, PPD, Barnas, PDK, PNI Marhaenisme, PPIB, PDP. Di antara lima belas partai politik tersebut, hanya PBB satu-satunya partai pengusung yang memiliki satu kursi di DPRD. Partai-partai tersebut mengusung pasangan calon dengan dasar penghitungan 15 persen perolehan suara pada Pemilu 2009.

Ir. Akhmad Fauzi, MA dengan Supeniwati melakukan perbuatan hukum berupa perjanjian pembagian tugas dan kewenangan apabila keduanya terpilih menjadi bupati dan wakil bupati Kabupaten Purworejo periode 2010-2015. Keduanya melakukan perjanjian yang dituangkan dalam akta autentik yang dibuat di hadapan notaris di Kabupaten Subagyo. Perjanjian tersebut menjadi kesepakatan awal keduanya untuk berkoalisi dalam mengikuti pencalonan pada Pilkada Kabupaten Purworejo 2010.

Dalam wawancara langsung yang dilakukan penulis pada Sabtu, 27 Januari 2018, Ir Akhmad Fauzi, MA menjelaskan bahwa, pernjanjian tersebut dibuat atas dasar pemikiran dari tim suksesnya dengan tim sukses bakal calon wakil bupati Supeniwati. Dalam diskusi dan dialog sebelum kedua tim tersebut sepakat berkoalisi pada pencalonan Pilkada Kabupaten Purworejo 2010, disepakati perlu adanya norma hukum yang mengikat atas kesepakatan keduanya untuk bekerjasama pada Pilkada tersebut. Sesuai dengan asas hukum perjanjian pucta sunt servanda, bahwa perjanjian akan menjadi dasar hukum bagi para pihak yang melakukan perjanjian, maka perjanjian kerjasama tersebut dibuat di hadapan notaris.

Penjelasan itu dibenarkan oleh Supeniwati melalui wawancara langsung yang dilakukan penulis pada Minggu, 28 Januari 2018. Supeniwati menjelaskan bahwa dirinya dan Ir. Akhmad Fauzi, MA bersepakat untuk kerjasama berpasangan dalam pencalonan Pilkada Kabupaten Purworejo 2010. Bentuk konkrit perjanjian tersebut adalah secara eksplisit mengatur tentang pembagian tugas dan kewenangan antara keduanya apabila terpilih menjadi bupati dan wakil bupati Purworejo.

Fauzi dan Supeniwati menjelaskan, keduannya bersepakat untuk melakukan perjanjian di awal karena belajar dari pengalaman di beberapa daerah, termasuk di Kabupaten Purworejo, di mana hubungan antara bupati dan wakil bupati tidak 
harmonis akibat ketidakjelasan tugas dan payung hukum yang mengatur. Oleh karena itu, keduanya berinisiatif membuat payung hukum yang mengikat dalam wujud perjanjian.

Landasan pikir yang mendorong keduanya untuk melakukan perjanjian adalah keberadaan dan latarbelakang keduanya yang sama-sama nonpartisan. Fauzi merupakan pensiunan birokrat mantan Sekretaris Daerah (Sekda) dan Supeniwati adalah kepala desa dan juga pengusaha. Keduanya sama-sama tidak terlibat langsung atau menjadi pengurus partai politik dari satu di antara partaipartai yang mengusung. Dengan demikian apabila keduanya tidak harmonis setelah terpilih, maka dampaknya kontraproduktif terhadap jalannya roda pemerintahan. Apalagi bargaining politik keduanya di hadapan DPRD lemah karena di antara lima belas partai yang mengusung, hanya PBB yang memiliki kursi di DPRD dan itupun jumlahnya hanya satu.

Fauzi dan Supeniwati menjelaskan, perjanjian yang diberi judul "Kerjasama Pencalonan Pilkada" tersebut secara umum mengatur tiga hal meliputi: Pertama, Pembagian tugas, pokok, dan fungsi bupati dan wakil bupati; Kedua, prioritas pembangunan sesuai dengan visi misi serta program kerja; dan Ketiga, pengaturan struktur organisasi tata kerja (SOTK) melalui penataan jabatan di lingkungan birokrasi.

Penjabaran dari tiga materi utama yang diperjanjikan tersebut dijelaskan Fauzi dan Supeniwati dengan diskripsi sebagai berikut: Pertama, terkait dengan pembagian tugas, pokok, dan fungsi bupati-wakil bupati, maka ketentuan secara normatif yang ada pada Undang-Undang Nomor 32 Tahun 2004 tetap dipedomani. Posisi bupati adalah kepala daerah yang bertanggungjawab sepenuhnya dalam penyelenggaraan pemerintahan daerah. Dalam menjalankan tugas tersebut, bupati dibantu wakil bupati.

Ketentuan normatif tersebut pada tingkat operasional dijabarkan dalam klausula yang diperjanjikan. Bupati sebagai kepala daerah mengambil kebijakankebijakan yang strategis dengan tetap melibatkan wakil bupati sebagai mitra. Wakil bupati diberikan tugas dan kewenangan untuk mengawal operasionalteknis dalam mengimplementasikan kebijakan yang strategis tersebut. Bupati 
melakukan tugas-tugas yang berkaitan dengan relasi eksternal, wakil bupati diberikan tugas melakukan konsolidasi internal dengan sama-sama melakukan koordinasi dan membangun sinergi.

Kedua, terkait dengan prioritas pembangunan, Fauzi dan Supeniwati membagi zona wilayah berdasarkan daerah asal masing-masing. Fauzi yang berasal dari wilayah selatan Purworejo bertanggungjawab untuk mengkonsolidasikan kegiatan prioritas pembangunan bagi wilayah selatan Purworejo yang mengambil garis tengah pembagian dari wilayah Kota Purworejo. Sedangkan Supeniwati yang berasal dari daerah utara Purworejo diberikan tanggung jawab dan kewenangan mengkonsolidasikan dan mengawal prioritas pembangunan wilayah utara Purworejo. Meskipun demikian, keduanya diharuskan saling berkoordinasi dan prioritas pembangunan harus tetap memedomani visi, misi, dan program kerja yang menjadi dokumen pada saat pencalonan.

Ketiga, terkait dengan penataan SOTK dan penempatan pejabat, Fauzi dan Supeniwati menuangkan dalam perjanjian bahwa tidak ada dominasi di antara keduanya dalam penempatan pejabat. Mutasi dan promosi pegawai dilakukan dengan saling berkoordinasi di antara keduanya dan mendasarkan pada regulasi serta mempertimbangkan profesionalitas dengan mengedepankan semangat reformasi di bidang birokrasi. Penataan SOTK dan penempatan pejabat tidak didasarkan pada semangat like and dislike serta menghindari politisasi birokrasi.

Selain tiga aspek tersebut, perjanjian yang dibuat antara Fauzi dengan Supeniwati juga memberikan pengaturan yang bersifat umum terkait dengan biaya pemenangan keduanya pada Pilkada Kabupaten Purworejo 2010. Dalam surat perjanjian tersebut, keduanya sepakat biaya pemenangan ditanggung secara bersama-sama secara proporsional dengan mendasarkan pada indikator pembagian zona wilayah pemenangan. Fauzi bertanggungjawab untuk pembiayaan kerja-kerja politik untuk pemenangan di delapan kecamatan meliputi Kecamatan Purworejo, Kecamatan Banyuurip, Kecamatan Kutoarjo, Kecamatan Ngombol, Kecamatan Grabag, Kecamatan Butuh, Kecamatan Bayan, dan Kecamatan Purwodadi. Sedangkan Supeniwati bertanggungjawab untuk kerjakerja politik untuk pemenangan di wilayah utara meliputi Kecamatan Bener, 
Kecamatan Loano, Kecamatan Kaligesing, Kecamatan Bagelen, Kecamatan Gebang, Kecamatan Bruno, Kecamatan Pituruh, dan Kecamatan Kemiri.

Fauzi dan Supeniwati menjelaskan, pembiayaan untuk kegiatan pemenangan itu tidak disebutkan nominalnya. Namun hanya ditegaskan bahwa pembiayaan dilakukan untuk kegiatan-kegiatan yang tidak bertentangan dengan regulasi Pilkada. Nominal biaya pemenangan tersebut secara detail diatur dalam laporan penerimaan dan penggunaan dana kampanye yang merupakan salah satu dokumen yang dipersyaratkan dalam pencalonan dan diserahkan kepada KPU.

Subagyo adalah notaris di Kabupaten Purworejo yang menyaksikan perbuatan hukum perjanjian antara Ir. Akhmad Fauzi, MA dengan Supeniwati. Dalam wawancara yang dilakukan penulis pada Senin, 29 Januari 2018, Subagyo menjelaskan bahwa dirinya sebagai pejabat umum berkeyakinan bahwa perbuatan hukum yang dilakukan antara Fauzi dengan Supeniwati tersebut diperbolehkan oleh undang-undang. Menurut Subagyo, perjanjian yang dilakukan antara Fauzi dengan Supeniwati tersebut telah memenuhi persyaratan sebagaimana ditentukan dalam Pasal 1320 KUHPerdata. Selain itu, Subagyo juga menjelaskan bahwa dirinya sebagai pejabat umum notaris memiliki kewenangan untuk membuat akta autentik atas kerjasama Fauzi dan Supeniwati karena mengacu pada ketentuan Pasal 15 Undang-Undang Nomor 2 Tahun 2014 tentang Perubahan Atas UndangUndang Nomor 30 Tahun 2004 tentang Jabatan Notaris. Pasal 15 ayat (1) undangundang tersebut berbunyi sebagai berikut:

Notaris berwenang membuat Akta autentik mengenai semua perbuatan, perjanjian, dan penetapan yang diharuskan oleh peraturan perundangundangan dan/ atau dikehendaki oleh yang berkepentingan untuk dinyatakan dalam Akta autentik, menjamin kepastian tanggal pembuatan Akta, menyimpan Akta, memberikan grosse, salinan dan kutipan Akta, semuanya itu sepanjang pembuatan Akta tidak juga ditugaskan atau dikecualikan kepada pejabat lain atau orang lain yang ditetapkan oleh undang-undang

Mendasarkan pada ketentuan pasal tersebut, Subagyo menjelaskan bahwa perjanjian kerjasama yang dijalin antara Fauzi dengan Supeniwati memang tidak diharuskan oleh peraturan perundang-undangan. Seperti diuraikan dalam pembahasan sebelumnya, perjanjian koalisi politik tersebut tidak termasuk yang 
dipersyaratkan KPU dalam pencalonan Pilkada. Namun demikian, Subagyo menjelaskan bahwa norma pasal tersebut juga menegaskan bahwa di samping notaris berwenang membuat akta autentik yang diharuskan peraturan perundang-undangan, juga ada norma hukum alternatif yang ada pada ketentuan pasal tersebut, yaitu "dikehendaki oleh para pihak yang berkepentingan". Artinya dalam konteks perbuatan hukum yang dilakukan oleh Fauzi dengan Supeniwati, keduanya yang merupakan para pihak dalam perjanjian tersebut memang menghendaki perjanjian tersebut dituangkan dalam akta autentik. Dengan demikian, kesedian Subayo dalam membuat akta autentik atas perbuatan hukum berupa perjanjian antara Fauzi dengan Supeniwati tersebut telah sesuai dengan ketentuan yang ada dalam UUJN.

\section{Perjanjian Bakal Calon Bupati dengan Partai Politik}

Dalam penelitian yang penulis lakukan terhadap pelaksanaan Pilkada Kabupaten Purworejo 2010, penulis juga menemukan adanya perbuatan hukum perjanjian yang mewarnai proses politik pada tahapan pra pencalonan, di mana perjanjian tersebut melibatkan para pihak yang terdiri dari bakal calon bupati dengan pimpinan partai politik. Perjanjian tersebut dilakukan sebelum memasuki tahapan resmi pencalonan yang ditetapkan dalam surat keputusan (SK) KPU Kabupaten Purworejo tentang tahapan, program, dan jadwal pelaksanaan Pilkada.

Perjanjian tersebut dilakukan oleh bakal calon H Daromi Irdjas, SH, M.Si yang pada Pilkada Kabupaten Purworejo 2010 diusung oleh gabungan partai politik yang memiliki kursi di DPRD. Ada lima partai politik yang mengusung HM Daromi Irdjas. Kelima partai tersebut adalah PAN yang memiliki 4 kursi, PPP, Partai Pemuda Indonesia (PPI), dan Partai Pelopor yang masing-masing memiliki satu kursi. Dengan demikian jumlah keseluruhan yang terkumpul dari koalisi gabungan partai politik yang mengusung HM Daromi Irdjas ini sebanyak 7 kursi, sehingga memenuhi batas minimal pengusungan calon, yaitu 15 persen jumlah kursi yang ada di DPRD Kabupaten Purworejo.

Berbeda dengan perjanjian antara bakal calon bupati Akhmad Fauzi dengan bakal calon wakil bupati Supeniwati yang dibuat dengan akta autentik, perjanjian Daromi ini dituangkan dalam akta di bawah tangan, namun dimintakan legalisasi kepada pejabat umum notaris. Perjanjian tersebut tidak dilakukan antara Daromi 
dengan seluruh pimpinan partai politik pengusung, namun hanya dengan pimpinan PAN sebagai pemilik kursi terbanyak dalam koalisi tersebut.

Ketua tim sukses Daromi, Amri Rosyadi dalam wawancara langsung dengan penulis menjelaskan, latar belakang dibuatnya perjanjian itu dikarenakan pihaknya memerlukan kepastian sikap politik PAN untuk mengusung Daromi. Dinamika politik yang terjadi pada saat pra pencalonan itu sangat cair, di mana PAN juga membuka ruang bakal calon lainnya untuk melakukan komunikasi politik. Posisi PAN sangat menentukan untuk kelangsungan koalisi gabungan partai politik tersebut untuk bisa menjadi "tiket" bagi Daromi untuk mendaftarkan diri sebagai calon bupati ke KPU Purworejo. Apabila PAN mundur dan meninggalkan koalisi tersebut, maka dipastikan koalisi itu akan bubar dan tidak bisa mengusung calon karena jumlah kursi dari ketiga partai itu tidak memenuhi syarat minimal jumlah kursi 15 persen untuk bisa mendaftarkan calon ke KPU.

HM Daromi Irdjas dalam wawancara langsung dengan penulis menjelaskan, sebelum sampai pada tahap kesepakatan yang ditandai dengan penandatanganan perjanjian tertulis, terlebih dahulu dilakukan proses-proses pembicaraan berupa negosiasi dan lobi antara tim suksesnya dengan pimpinan PAN. Dalam tahapan pra perjanjian tersebut dibicarakan hak dan kewajiban dari masing-masing pihak. Proses ini dipahami sebagai periode-periode yang memang harus dilalui dalam sebuat kontrak perjanjian.

Sebagaimana dijelaskan oleh Ridwan Khairandy, dalam sebuah kontrak terlebih dahulu harus dilalui periode atau fase yang terbagi dalam tiga periode, yakni Pertama periode prakontrak (pre contractual period); Kedua periode pelaksanaan kontrak (contractual performance period; dan Ketiga periode pascakontrak (post contractual period).

Terkait dengan periode atau fase tersebut, Amri Rosadi menjelaskan, langkah awal dimulai dengan melakukan tahapan prakontrak di mana masing-masing pihak, baik perwakilan yang diberikan kuasa oleh Daromi maupun perwakilan

${ }^{4}$ Ridwan Khairandy, Hukum Kontrak Indonesia Dalam Perpespektif Perbandingan (Bagian Pertama), FH UII Press, Yogyakarta, 2013, hlm. 70. 
dari PAN melakukan musyawarah, negosiasi, dan lobi-lobi, di mana masingmasing pihak menyampaikan keinginannya. Pada periode negosiasi ini tidak hanya dilakukan sekali saja, tapi dilakukan sampai berkali-kali.

Pada tahap prakontrak ini, akhirnya berhasil mencapai kesepakatan terkait dengan hak dan kewajiban masing-masing pihak. Selanjutnya perwakilan dari kedua belah pihak secara bersama-sama menyusun konsep perjanjian secara tertulis yang isinya merupakan kesepakatan-kesepakatan yang didapatkan dari proses musyawarah, negosiasi, dan lobi-lobi.

Tahap berikutnya adalah pelaksanaan kontrak perjanjian, yakni pihak Daromi bersama tim suksesnya dan pihak PAN yang diwakili Ketua DPD PAN Kabupaten Purworejo Drs. Zusron MM dan Sekretaris HM Iwan Fadjarudin menandatangani perjanjian yang tertuang dalam akta di bawah tangan tersebut. Penandatanganan di atas materai tersebut dilakukan di hadapan pejabat umum Notaris Imam Supingi untuk mendapatkan legalisasi.

Pada tahapan berikutnya dari proses perjanjian tersebut adalah periode pascakontrak, di mana perbuatan hukum berupa perjanjian antara Daromi dengan pimpinan PAN tersebut diumumkan kepada publik. Pengumuman tersebut dilakukan dengan menggelar konferensi pers di media yang pada pokoknya menyampaikan kepada publik bahwa PAN secara resmi mengusung Daromi sebagai calon bupati pada Pilkada Kabupaten Purworejo berkoalisi dengan tiga partai, yaitu PPP, PPI, dan Partai Pelopor.

Ketua DPD PAN Kabupaten Purworejo Drs. Zusron MM dalam wawancara langsung dengan penulis menjelaskan, sesuai dengan AD/ART dari PAN, Ketua DPD diberikan kewenangan untuk melakukan negosiasi dan lobi-lobi politik dalam rangka mendapatkan calon yang akan diusung dalam setiap pelaksanaan Pilkada. Kewenangan tersebut secara otomatis juga dimilikinya dalam proses penjaringan calon untuk diputuskan sebagai calon yang diusung pada Pilkada Kabupaten Purworejo.

Zusron menjelaskan, sebelum memutuskan mengusung Daromi, PAN memang terlebih dahulu melakukan komunikasi dan penjajagan politik dengan para bakal calon yang muncul menjelang pelaksanaan Pilkada. Komunikasi dan penjajagan tersebut dalam rangka untuk mendapatkan kesamaan visi dan misi 
antara bakal calon dengan platform yang diperjuangkan PAN. Namun akhirnya dari sekian banyak bakal calon yang sudah komunikasi dengan PAN, Daromi yang dipandang layak untuk diusung di samping karena tercapainya kesepakatankesepakatan yang kemudian dituangkan dalam perjanjian tertulis melalui akta bawah tangan yang dilegalisasi di kantor notaris Imam Supingi.

Zusron menjelaskan, dalam perjanjian tertulis antara PAN dengan Daromi, beberapa di antaranya yang diatur adalah hak dan kewajiban dari masing-masing pihak. Hak utama yang didapatkan Daromi sekaligus menjadi kewajiban dari PAN dalam perjanjian tersebut adalah dukungan politik yang dituangkan dalam surat rekomendasi yang digunakan sebagai syarat untuk pendaftaran sebagai calon ke KPU. Sedangkan hak-hak yang didapatkan PAN sekaligus menjadi kewajiban dari Daromi adalah sebagai berikut:

1. PAN mendapatkan prioritas utama yang selalu dilibatkan dalam proses pembahasan untuk menentukan calon wakil bupati yang mendampingi Daromi;

2. PAN sebagai pemilik kursi terbanyak mendapatkan hak terbanyak dalam struktur tim sukses untuk pemenangan;

3. PAN sebagai pemilik kursi terbanyak mendapatkan hak untuk menempatkan saksi tempat pemungutan suara (TPS) terbanyak dibandingkan partai-partai pengusung lainnya;

4. PAN dilibatkan secara keseluruhan dalam proses politik yang berkaitan dengan pemenangan Pilkada;

5. Apabila Daromi terpilih menjadi bupati, maka PAN berhak atas bantuan dari Daromi untuk membesarkan partai;

6. Apabila Daromi terpilih menjadi bupati, maka PAN berhak mendapatkan prioritas untuk dilibatkan dalam pembahasan dan penyusunan APBD Kabupaten Purworejo yang harus difokuskan pada program-program peningkatan kesejahteraan rakyat sesuai dengan platform dan garis perjuangan PAN; 5

Selain mengatur tentang hak dan kewajiban dari masing-masing pihak, perjanjian koalisi politik antara Daromi dengan PAN juga mengatur sanksi-sanksi. Zusron menjelaskan, dalam perjanjian tersebut antara lain diatur mengenai sanksi apabila salah satu pihak melakukan ingkar janji atau wanprestasi bisa diajukan gugatan oleh pihak lainnya ke pengadilan. Gugatan tersebut berwujud gugatan

${ }^{5}$ Wawancara dengan Ketua DPD PAN Kabupaten Purworejo Drs Zusron MM pada Senin, 29 Januari 2018. 
perdata berupa ganti rugi sebesar Rp 5.000.000.000,- sekaligus gugatan pidana. Dalam penyelesaian apabila terjadi sengketa, kedua belah pihak menyatakan akan diselesaikan secara musyawarah. Apabila musyawarah tidak berhasil menyelesaikan sengketa, maka kedua belah pihak memilih menempuh jalur hukum dengan memiliki domisili hukum di Pengadilan Negeri (PN) Purworejo.

\section{Implikasi Yuridis Perjanjian Koalisi Politik pada Pilkada Kabupaten Purworejo 2010}

Setelah melakukan pembahasan tentang pelaksanaan perjanjian koalisi politik yang terjadi selama pelaksanaan Pilkada Kabupaten Purworejo 2010, pada sub bab ini penulis akan melakukan pembahasan terkait dengan implikasi yuridis atas perjanjian koalisi politik tersebut. Pembahasan dilakukan dengan menguraikan antara fakta atas pelaksanaan perjanjian yang dikaitkan dengan kajian teori sebagaimana diuraikan serta mengacu pada pandangan praktisi yang terkait dengan materi pembahasan dari obyek penelitian ini.

Dalam perspektif kajian regulasi pelaksanaan Pilkada, perjanjian kerjasama politik yang dilakukan antara calon bupati Ir. Akhmad Fauzi MA., dengan Supeniwati tidak memiliki implikasi yuridis apapun yang berpengaruh terhadap tahapan Pilkada. Keberadaan surat perjanjian tersebut, meskipun dituangkan dalam akta autentik tidak memiliki dampak yuridis secara langsung yang bisa berpengaruh terhadap sah dan tidaknya status keduanya sebagai pasangan calon yang ditetapkan oleh penyelenggara Pilkada, dalam hal ini KPU Kabupaten Purworejo.

Demikian juga dengan perjanjian kesepakatan politik yang dibuat calon bupati HM. Daromi Irdjas, SH. MS.I dengan PAN sebagai partai pengusungnya maupun pejanjian tertulis antara calon Bupati Drs. Yuniarso Kwartono Adi dengan PKB sebagai pengusungnya. Meskipun secara kedua perjanjian tersebut dituangkan dalam akta di bawah tangan yang dilegalisasi di notaris, namun dalam perspektif regulasi Pilkada tidak memiliki implikasi hukum apapun. Artinya keberadaan perjanjian koalisi politik secara tertulis tersebut tidak berpengaruh terhadap sah tidaknya dalam penetapan pasangan calon sebagai peserta Pilkada.

Apabila dilihat tahapan-tahapan pelaksanaan perjanjian, memang memenuhi ketentuan-ketentuan normatif sebagaiman diatur dalam hukum perjanjian sebagaimana diatur dalam Pasal 1320 KUHPerdata. Namun karena obyek yang 
diperjanjikan adalah kegiatan politik, maka surat perjanjian tersebut tidak memiliki implikasi hukum. Surat perjanjian itu bisa dilihat sebagai bagian dari dinamika dalam penggalangan dukungan atau bahkan bisa disebut sebagai manuver-manuver politik sebelum akhirnya benar-benar adanya kesepakatan dari para pihak untuk mendukung atau bekerjasama dalam pencalonan pada Pilkada Kabupaten Purworejo 2010.

Ketua KPU Kabupaten Purworejo periode 2008 - 2013 Muslikhin Madiani dalam wawancara langsung dengan penlis menjelaskan bahwa, Undang-Undang Nomor 32, Undang-Undang Nomor 12 Tahun 2008, maupun regulasi Pilkada yang ada pada Peraturan Komisi Pemilihan Umum (PKPU) sama sekali tidak mengatur atau bahkan mensyaratkan keharusan adanya perjanjian komitmen politik di antara para calon, baik itu calon bupati maupun calon wakil bupati.

Secara normatif, pengajuan pasangan calon pada Pilkada Kabupaten Purworejo 2010 diatur secara eksplisit hanya melalui dua jalur. Yakni, Pertama, diusung oleh partai politik atau gabungan partai politik dengan syarat memenuhi jumlah 15 persen kursi di DPRD atau mendasarkan pada jumlah perolehan suara sah sebanyak 15 persen dari Pemilu 2009. Kedua, melalui jalur perseorangan dengan persyaratan penyerahan dukungan sebesar 4 persen dari total jumlah penduduk. Di luar jalur tersebut, tidak ada jalur lain dalam pengusungan pasangan calon. Bakal calon akan ditetapkan sebagai peserta Pilkada secara berpasangan apabila memenuhi ketentuan syarat normatif sebagaimana ditentukan regulasi untuk pengusungan pasangan calon, baik dari jalur partai politik maupun gabungan partai politik dan jalur perseorangan.

\section{Penutup}

Berdasarkan uraian dalam pembahasan di atas, penulis dapat menarik kesimpulan untuk menjawab rumusan masalah pada penelitian tesis ini sebagai berikut: pertama, dalam pelaksanaan Pilkada Kabupaten Purworejo 2010, terjadi dinamika yang cukup menarik, yaitu adanya perbuatan hukum berupa perjanjian koalisi dan atau perjanjian komitmen politik. Perbuatan hukum ini dilakukan calon bupati dengan calon wakil bupati serta para pimpinan partai politik yang mengusung pasangan calon. Dalam pelaksanaanya, ada dua jenis para pihak yang 
melakukan perjanjian. a. perjanjian dilakukan oleh calon Bupati Ir. H. Akhmad Fauzi, MA., dengan calon Wakil Bupati Supeniwati. Perjanjian keduanya dilakukan pada pra pencalonan. Obyek perjanjiannya adalah pembagian tugas dan kewenangan bupati dan wakil bupati apabila keduanya terpilih. Perjanjian juga mengatur tentang pembagian tugas pemenangan selama pelaksanaan Pilkada Kabupaten Purworejo 2010. Perjanjian antara Ir. Akhmad Fauzi dengan Supeniwati ini dituangkan dalam akta autentik yang dibuat oleh Notaris Subgyo. b. perjanjian yang dilakukan antara calon bupati HM. Daromi Irdjas, SH, M.Si dengan PAN sebagai pengusung yang diwakili Ketua DPD Drs Zusron serta perjanjian yang dilakukan antara calon bupati Drs. Yuniarso Kwartono Adi dengan PKB sebagai partai pengusung yang diwakili oleh Ketu Tim 9 Thoha Mahasin. Tim 9 ini merupakan tim yang dibentuk DPC PKB Kabupaten Purworejo untuk melakukan penjaringan, penelitian, dan penentuan calon yang akan diusung pada Pilkada Kabupaten Purworejo 2010. Perjanjian yang dilakukan antara calon dengan partai politik ini dilakukan dengan akta di bawah tangan namun tetap dimintakan legalisasi kepada notari. Perjanjian HM. Daromi Irdjas dengan PAN dilegalisasi ke Kantor Notaris Imam Supingi, sedangkan perjanjian antara Yuniarso Kwartono Adi dengan PKB dilegalisasi ke Kantor Notaris Subagyo. Dengan demikian, seluruh proses perjanjian koalisi politik dan atau komitmen politik yang dilaksanakan pada Pilkada Kabupaten Purworejo 2010 melibatkan tugas pokok dan fungsi pejabat umum notaris, baik dalam kewenangannya membuat akta autentik maupun kewenangan melakukan legalisasi dan mencatatnya dalam buku khusus.

Kedua, ketiga perjanjian yang dilaksanakan pada Pilkada Kabupaten Purworejo 2010 tersebut prosesnya melalui tahapan-tahapan sebagaimana diatur dalam hukum perjanjian. Yakni kedua belah pihak terlebih dahulu melalui fase prakontrak, yaitu musyawarah dan negosiasi untuk mencapai kesepakatan mengenai hak dan kewajiban masing-masing pihak dalam surat perjanjian tersebut. Secara keseluruhan, ketiga perjanjian tersebut telah memenuhi persyaratan-persyaratan normatif sebagaimana diatur dalam Pasal 1320 KUHPerdata; Ketiga, perjanjian koalisi politik dan atau perjanjian komitmen politik tersebut tidak memiliki implikasi hukum secara langsung terhadap pelaksanaan 
Pilkada Kabupaten Purworejo 2010. Dalam perspektif hukum tata negara, perbuatan hukum perjanjian itu, meskipun dituangkan dalam akta autentik ternyata tidak berpengaruh terhadap sah tidaknya posisi pasangan calon sebelum pendaftaran. Bahkan meskipun tanpa adanya perjanjian tersebut, pasangan calon tidak akan dinyatakan gugur dari posisinya sebagai peserta Pilkada sepanjang persyaratan pencalonan sebagaimana diatur dalam regulasi Pilkada terpenuhi. Artinya perjanjian koalisi dan atau perjanjian komitmen politik tidak menjadi bagian dari persyaratan yang ditentukan oleh regulasi Pilkada. Keempat, di antara tiga perjanjian yang terjadi pada pelaksanaan Pilkada Kabupaten Purworejo tahun 2010, dua di antaranya terjadi wanprestasi. Namun demikian, pihak yang merasa dirugikan karena tindakan wanprestasi tersebut tidak melakukan upaya hukum dengan mengajukan gugatan ke pengadilan. Berdasarkan hal itu, sebenarnya para pihak menganggap bahwa perjanjian itu cukup lemah apabila dijadikan sebagai bukti pengajuan gugatan. Sebab obyek yang diperjanjian itu politik sehingga sulit untuk mengukurnya. Perjanjian tersebut kemudian dipahami sebagai tindakan untuk memberikan ketenangan psikologis di antara para pihak pada saat pra pencalonan. Apabila dijadikan alat bukti untuk mengajukan gugatan hukum diyakini sangat lemah.

Setelah melakukan pembahasan hasil penelitian tesisi ini, penulis merekomendasikan saran-saran sebagai berikut: pertama, penelitian-penelitian dengan obyek perjanjian atau kontrak-kontrak politik masih harus banyak dilakukan di masa-masa mendatang. Sebab kontrak-kontrak dan perjanjian dengan obyek politik saat ini semakin banyak dilakukan oleh masyarakat, sedangkan norma hukum yang secara khusus mengaturnya masih sangat sedikit. Acuan kontrak perjanjian yang diatur dalam hukum perdata cenderung lemah untuk diterapkan dalam perjanjian-perjanjian dengan obyek politik. Di sinilah perlunya penelitian-penelitian lanjutan untuk menggali pemikiran-pemikiran yang melahirkan norma-norma hukum baru terkait dengan kontrak politik. Kedua, kebutuhan masyarakat di masa mendatang dalam melakukan kontrak hukum semakin banyak. Bukan hanya untuk kepentingan kepedartaan saja, tapi juga di wilayah politik. Di samping dalam pelaksanaan Pilkada, praktik perjanjian politik 
juga banyak dilakukan pada saat pencalonan pemilu legislatif. Perjanjian tersebut juga melibatkan notaris, baik untuk pembuatan akta autentik, legalisasi, atau sekedar warmeking dari surat pernyataan yang dibuat calon. Tuntutan masyarakat yang mengharapkan peran notaris untuk memberikan legitimasi dari kontrakkontrak yang berkaitan dengan kegiatan politik ini tentu harus dijawab dengan kesiapan skill maupun perangkat lainnya. Perkumpulan notaris hendaknya mulai memikirkan untuk membuat semacam panduan atau standar operasional yang baku dan dijadikan pedoman bagi notaris apabila membuat kontrak-kontrak yang berkaitan dengan kegiatan politik. Dengan demikian, notaris benar-benar mampu menjawab kebutuhan masyarakat dalam berkontrak yang semakin kompleks di masa-masa yang akan datang.

\section{Daftar Pustaka}

\section{Buku}

Bakti, Kartini Muljadi dan Gunawan Widjaja, Perikatan Yang Lahir dari Perjanjian, PT Raja Grafindo, Persada, 2006.

Deddy, Mulyana, Metodologi Penelitian Kualitatif ; Paradigma Baru Ilmu Komunikasi dan Ilmu Sosial Lainnya, PT Remaja Rosidakarya, Bandung, 2004.

Harahap, M. Yahya Segi-Segi Hukum Perjanjian, Penerbit Alumni, Bandung, 1986.

HS, Salim, Teknik Pembuatan Akta Satu, Konsep Teoritis, Kewenangan Notaris, Bentuk dan Minuta Akta, PT Raja Grafindo Persada, Jakarta, 2015.

Mertokusumo, Sudikno, Hukum Acara Perdata Indonesia, Yogyakarta: Liberty, 1981.

Moh. Mahfud MD,Politik Hukum di Indonesia, Cet 4, PT Raja Grafindo Persada, Jakarta, 2011.

Soebekti, R. Hukum Perjanjian, Intermasa, Jakarta, 1979.

Soekanto, Soerjono dan Sri Mamuji, Penelitian Hukum Normatif-Suatu Tinjauan Singkat, Rajawali Press, Jakarta, 1985.

Soekanto, Soerjono, Pengantar Penelitian Hukum, UI Press, cetakan 3, Jakarta, 1998.

Soimin, Soedharyo, Kitab Undang-Undang Hukum Perdata, Sinar Grafika, Jakarta, 1999.

Solahudin, Kitab Undang-Undang Hukum Perdata, Visimedia, 2008.

Suharjono, "Varia Peradilan Tahun XI Nomor 123, Sekilas Tinjauan Akta Menurut Hukum, Desember 1995. 
Syamsudin, M., Operasionalisasi Penelitian Hukum, PT Raja Grafindo Persada, Jakarta, 2007.

Tim Bappeda Kabupaten Purworejo, Purworejo Dalam Angka, Bagian Humas Setda, Purworejo, 2009.

Tim KPU Kabupaten Purworejo, Laporan Penyelenggaraan Pilkada Kabupaten Purworejo Tahun 2010, KPU Purworejo, 2010.

\section{Peraturan Perundang-undangan}

Undang-Undang Dasar 1945

Kitab Undang-Undang Hukum Perdata

Undang-Undang Nomor 2 Tahun 2014 tentang Perubahan Undang-undang Nomor 30 tahun 2004 tentang Jabatan Notaris

Undang-Undang Nomor 22 Tahun 2008 tentang Revisi Undang-undang Nomor 32 Tahun 2004 tentang Pemerintahan Daerah

\section{Internet}

https:/ / nasional.sindonews.com/read/860024/18/budaya-kontrak-politik1399102380/13 diakses Jumat, 17 Nopember 2017 pukul 10.15 WIB 